\title{
ADVERSE EVENTS INDUCED BY ANTI-INFECTIVES IN HOSPITALIZED PATIENTS
}

Vojislav Cupurdija ${ }^{1}$, Zorica Lazic ${ }^{1,2}$, Slobodan Jankovic ${ }^{2,3}$, Olgica Gajovic ${ }^{2,4}$, Ivan Cekerevac ${ }^{1}$, Ljiljana Novkovic ${ }^{1,2}$, Marina Petrovic ${ }^{1,2}$, Nela Djonovic ${ }^{2}$ ${ }^{1}$ Center for Pulmonary Diseases, Clinic for Internal Medicine, Clinical Center Kragujevac, Serbia

${ }^{2}$ University in Kragujevac, Medical Faculty, Kragujevac, Serbia

${ }^{3}$ Center for Clinical and Experimental Pharmacology, Clinical Center Kragujevac, Serbia

${ }^{4}$ Clinic for Infective Diseases, Clinical Centre Kragujevac, Serbia

\section{NEŽELJENI DOGADAJI UZROKOVANI PRIMENOM ANTIMIKROBNE TERAPIJE KOD HOSPITALIZOVANIH PACIJENATA}

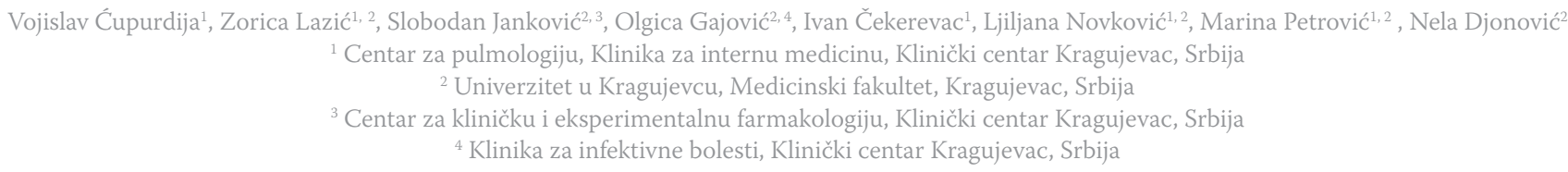

\section{ABSTRACT}

Introduction. The objective of this study was to obtain accurate data about adverse events (AEs) related to antimicrobial therapy, including rate, causality, outcome and circumstances in which they occurred.

Methods. Hospitalizised patients undergoing treatment with one or more anti-infective drugs were eligible for the study. The main outcome measures were any adverse clinical signs, symptoms or laboratory test abnormalities that had likely been induced by an anti-infective agent. The seriousness and causality of the AEs were classified on the basis of WHO recommendations and compared with results from the Naranjo Probability Scale, European Causality Categories (ABO system) and French Imputation System assessments.

Results. During the 6-month study period, 421 patients (72.84\%) received at least one anti-infective drug. Thirtyone patients (7.36\%) were found to have anti-infectiveinduced AEs. Anti-tuberculosis agents caused the highest percentage of AEs (38.7\%) during the period of observation. The majority of AEs presented as disorders of the gastrointestinal tract (41.9\%).

Conclusion. AEs in females tend to last longer than in males. Males have a greater risk of experiencing AEs caused by fluoroquinolones (e.g., ciprofloxacin), while female patients have a greater risk of experiencing AEs caused by anti-tuberculosis agents. The incidence of AEs in inpatients receiving anti-infectives in our study (7.36\%) is within the range reported from other studies. There is a great need for the development of new causality assessment scales that have better sensitivity and specificity.

Key words: adverse drug event, anti-infective agents, hospitalisation

\section{SAŽETAK}

Uvod. Cilj studije je da se utvrde precizni podaci o neželjenim dogadajima uzrokovanim primenom antimikrobne terapije, o stopi njihove učestalosti, uzročnosti, ishodu i okolnostima pod kojima su se pojavile.

Metode. Posmatrani su pacijenti koji su tokom hospitalnog lečenja bili tretirani anti-infektivnim lekovima $i$ kod kojih je došlo do pojave neželjenog kliničkog znaka, simptoma ili abnormalnosti laboratorijskih nalaza, za koje se može postaviti sumnja da su indukovani primenom anti-infektivne terapije. Težina i uzročnost neželjenih događaja vezanih za primenu lekova (NDL) su klasifikovane na osnovu preporuka SZO i potom poredene sa rezultatima dobijenim iz analize Naranjo skale verovatnoće, Evropskih kategorija kauzalnosti (ABO sistem) $i$ Francuskog sistema za utvrđivanje kauzalnosti.

Rezultati. Tokom 6-mesečnog studijskog perioda, 421 pacijent (72.84\%) je dobio najmanje jedan anti-infektivni lek. Kod 31 pacijenta (7.36\%) je uočen neželjeni događaj, za koji je postavljena sumnja da je uzrokovan primenom anti-infektivne terapije. Najveći procenat NDL u posmatranom periodu je bio uzrokovan antituberkuloticima (38.7\%). Većina neželjenih dejstava lekova se pojavila kao poremećaji digestivnog trakta (41.9\%).

Zaključak. Neželjena dejstva kod žena imaju tendenciju da traju duže nego kod muškaraca. Muškarci imaju veći rizik da iskuse neželjene događaje uzrokovane fluorohinolonima (ciprofloksacin) od žena, dok su žene u većem riziku da iskuse neželjene događaje uzrokovane antituberkuloticima. Incidenca NDL kod pacijenata u našoj studiji koji su primali antiinfektivnu terapiju (7.6\%) je u proseku rezultata koje su dale druge studije koje su se bavile sličnim problemom. U zaključku se nameće velika potreba za razvojem novih skala za procenu kauzalnosti, sa boljom senzitivnošću i specifičnošću.

Ključne reči: neželjeni događaj povezan sa primenom leka, anti-infektivni agensi, hospitalizacija.

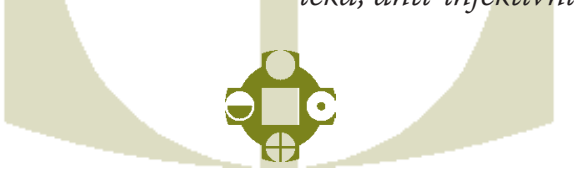

UDK: 615.28.06 / Ser J Exp Clin Res 2011; 12 (3): 97-101 


\section{INTRODUCTION}

Adverse drug reactions (ADRs) are very common in everyday medical practice and cause various problems for patients and physicians, not only the with regard to their management but also in their recording, classification and assessment. They are regarded not only as a medical issue but also as an economic problem asbecause they often lead to an increase in the length of hospitalisation and a need to administer additional medications. An estimation made in France in 2001 suggested that increased ADR-induced costs result especially from the prolongation of hospitalisation, with the average cost increase calculated at 4150 euros per ADR. ${ }^{[1]}$ A prospective analysis of 18820 patients in Britain projected the annual National Health Service costs of hospital admissions due to ADRs of up to 706 million euros. ${ }^{[2]}$

The importance of this problem is imposing the need to conduct more studies on drug safety and assessment of various adverse events. These results may greatly influence medical practice in the future, leading to safer and more rational therapy. This would greatly benefit patients and health systems overall. The severity and substantial costs of ADRs in hospitals justify investments aimed at preventing these events. ${ }^{[3]}$

The incidence of ADRs in hospitalised patients ranges from $1.5 \%$ to $35 \% \%^{[4,5]}$, depending on various factors. Antiinfective agents are responsible for approximately $25 \%$ of ADRs in hospitalised patients. ${ }^{[6]}$

However, the true incidence of ADRs in hospital departments specialised for the care of patients with disorders of a single organ system remains to be established. The aim of our study was to investigate the rates and types of adverse events related to antimicrobials among patients with pulmonary disorders.

\section{METHODS}

The study was planned as a prospective, crosssectional study, and it was conducted at the Center for Pulmonary Diseases of the Clinic for Internal Diseases, Clinical Center Kragujevac, Serbia, over a 6-month period from December 2005 until May 2006. The Center for Pulmonary Diseases has a capacity of 60 beds, and it was assumed that approximately 600 patients would be hospitalised during this 6-month period. Only hospitalised patients receiving one or more anti-infective drugs were eligible for the study. The most common reasons for hospitalisation and administration of anti-infective therapy were the following: infections of the lower respiratory tract, lung tuberculosis and exacerbation of chronic obstructive pulmonary disease (COPD). Each patient's health status, both subjective and objective, and the results of haematology and biochemistry laboratory tests were regularly assessed to identify and record ad- verse events (AEs). Patients were interviewed and physically examined on a daily basis during hospitalisation. If any abnormal clinical signs, symptoms or laboratory tests were detected that had likely been induced by an anti-infective agent, the investigator completed a pre-designed form/questionnaire.

The data obtained from the adverse event (AE) causality assessment using the WHO Causality Categories ${ }^{[7,8]}$ were compared with data obtained for each $\mathrm{AE}$ from an analysis performed based on the Naranjo Probability Scale ${ }^{[9]}$, European Causality Categories (ABO system) ${ }^{[10]}$ and the French Imputation System ${ }^{[11]}$.

The pre-designed form/questionnaire that was used to record AEs related to anti-infectives contained general information on the patient (name, age, sex, weight, occupation) and information concerning his/her disease, length of hospitalisation, concomitant medications, a brief description of the AE, time of onset, duration, information concerning drug discontinuation and eventual re-administration, results of laboratory analyses, previous experience with adverse reactions to drugs, information on the drug and drug package and the outcome of the AE.

All verified AEs were also reported to the Serbian National Pharmacovigilance Center using a special form the.

\section{Statistical analysis}

All experimental and clinical data were processed using SPSS software for Windows 11.0. For statistical data processing, objective mathematical and statistical tests and methods were used, which were completely adapted to the type and extent of information.

We used descriptive statistics and non-parametric statistical tests (Chi-squared test, Spearmann rank-correlation) and non-parametric analysis (Kruscal-Wallis test). The results were considered significant if $\mathrm{p} \leq 0.05$.

\section{RESULTS}

During the study period, a total of 578 patients were hospitalised. The average age of patients was $63.34 \pm 14.25$ years, and the overall average length of hospitalisation was $18.16 \pm 14.36$ days. The average length of hospitalisation in patients receiving anti-tuberculosis agents was $49.05 \pm 22.46$ days, and the average length in patients receiving all other anti-infectives was $15.86 \pm 13.42$ days. Four hundred twentyone patients $(72.84 \%)$ received at least one anti-infective drug and were therefore eligible to enter the study. AEs induced by anti-infectives were recorded in 31 patients (7.36\%). All AEs caused by anti-infective drugs occurred during hospitalizisation. The average length of hospitalisation in patients who experienced AEs was $20.13 \pm 11.53$ days.

Of the 31 patients who experienced AEs, 15 were males $(48.39 \%)$ and 16 were females (51.61\%). Of the 421 patients who received anti-infectives, 111 (26.36\%) 
Table I. Number of prescriptions of anti-infective agents during the study period

\begin{tabular}{|l|l|}
\hline Anti-infective agent & $\begin{array}{l}\text { No. of pre- } \\
\text { scriptions }\end{array}$ \\
\hline Fluoroquinolones & 150 \\
\hline Cephalosporins & 111 \\
\hline Macrolides & 83 \\
\hline Aminoglycosides & 78 \\
\hline Sulphonamides & 54 \\
\hline Penicillin $(+\beta$-lactamase inhibitors) & 47 \\
\hline Anti-tuberculosis agents 4-drug therapy & 36 \\
\hline Anti-tuberculosis agents 5-drug therapy & 4 \\
\hline Lincosamides & 11 \\
\hline Metronidazole & 7 \\
\hline Carbapenems & 4 \\
\hline Fluconasole & 4 \\
\hline Tetracyclines & 3 \\
\hline Glycopeptides & 2 \\
\hline
\end{tabular}

Table III. Results of the causality assessment using the European Causality Categories - ABO system

\begin{tabular}{|l|l|l|}
\hline Categories & Frequency & Per cent \\
\hline A & 18 & 58 \\
\hline B & 13 & 42 \\
\hline O & 0 & 0 \\
\hline
\end{tabular}

A The reports include good reasons and sufficient documentation to assume a plausible, conceivable, likely, but not necessarily highly probable, causal relationship .

B The reports contain sufficient information to accept the possibility of a causal relationship (not impossible and not unlikely), although the connection is uncertain and may be even doubtful, e.g., because of missing data, insufficient evidence or the possibility of another explanation.

O In the reports, causality is, for one reason or another, not assessable, e.g., because of missing or conflicting data.

Table IV. Results of the causality assessment using the Naranjo Probability Scale

\begin{tabular}{|l|l|l|}
\hline Categories & Frequency & Per cent \\
\hline $9+$ (Highly probable) & 0 & 0 \\
\hline $5-8$ (Probable) & 22 & 70 \\
\hline $1-4$ (Possible) & 9 & 30 \\
\hline $0-($ Doubtful) & 0 & 0 \\
\hline
\end{tabular}

Clin Pharmacol Ther 1981;30: 239-45

Table V. Results of the causality assessment using

The French Imputation System

\begin{tabular}{|l|l|l|}
\hline Categories & Frequency & Per cent \\
\hline I 4 - Very likely & 8 & 25 \\
\hline I 3 - Likely & 10 & 32.3 \\
\hline I 2 - Possible & 10 & 32.3 \\
\hline I 1 - Dubious & 3 & 10.4 \\
\hline I 0 - Unlikely (appears excluded) & 0 & 0 \\
\hline
\end{tabular}

Thérapie 1985; 40: 111-8
Table II. Results of the causality assessment using the WHO Causality Categories

\begin{tabular}{|l|l|l|}
\hline Categories & Frequency & Per cent \\
\hline Certain & 9 & 29 \\
\hline Probable & 11 & 35.5 \\
\hline Possible & 10 & 32.3 \\
\hline Unlikely & 1 & 3.2 \\
\hline Conditional/Unclassified & 0 & 0 \\
\hline Unassessable/Unclassifiable & 0 & 0 \\
\hline
\end{tabular}

\section{- Certain}

- Event or laboratory test abnormality, with plausible time relationship to drug intake

- Cannot be explained by disease or other drugs

- Plausible response to withdrawal (pharmacologically, pathologically)

- Definitive event confirmed pharmacologically or phenomenologically (An objective and specific medical disorder or a recognised pharmacological phenomenon)

- Rechallenge (if necessary)

- Probable

- Event or laboratory test abnormality, with reasonable time relationship to drug intake

- Unlikely to be attributed to disease or other drugs

- Response to withdrawal clinically reasonable

- Rechallenge not necessary

- Possible

- Event or laboratory test abnormality, with reasonable time relationship to drug intake

- Could also be explained by disease or other drugs

- Information on drug withdrawal lacking or unclear

- Unlikely

- Event or laboratory test abnormality, with a time relationship with the drug that makes a relationship improbable (but not impossible)

- Diseases or other drugs provide plausible explanations

\section{- Conditional / Unclassified}

- Event or laboratory test abnormality

- More data for proper assessment needed

- Additional data under examination

\section{- Unassessable / Unclassifiable}

- A report suggesting an adverse reaction

- Cannot be judged because of insufficient or contradictory information

- Report cannot be supplemented or verified

Drug Safety 1994;10:93-102

were treated with a monotherapeutic regimen (one antiinfective drug), and 310 (73.64\%) were treated with combinations of two or more anti-infective drugs. The most commonly prescribed anti-infective drugs were fluoroquinolones (150 prescriptions recorded in the 6-month period), cephalosporins (111 prescriptions), macrolides (83 prescriptions), aminoglycosides (78 prescriptions) and sulphonamides (54 prescriptions). (Table I)

All recorded AEs were analysed and assessed using 4 scales/methods for AE assessment (WHO, Naranjo scale, $\mathrm{ABO}$ scale, French Imputation Method). Depending on the scale that was used, the percentage of AEs that were estimated as certain/the most probable varied from 58\% (ABO scale), to 29\% (WHO), to 25.8\% (French Imputation Method) and to 0\% (Naranjo scale). (Tables II, III, IV, V) 
Anti-tuberculosis drugs caused the highest percentage of AEs in the observed period (38.7\%).

AEs that occurred in patients during treatment with anti-infectives affected different system-organ classes. The majority of AEs presented as disorders of the gastrointestinal tract $(41.9 \%)$, followed by disturbances in laboratory parameters in $22.6 \%$ (mostly increased levels of uric acid, AST and/or ALT), hypersensitivity reactions (urticaria) (16.1\%), skin disorders (rash) (9.7\%), general disorders (weakness) (6.5\%) and damaged acoustic nerve/vertigo (3.2\%). In the gastrointestinal category, diarrhoea was the most frequent complication (71.4\%), followed by nausea and vomiting.

The main causal drugs were anti-tuberculosis agents (rifampicin, isoniazid, pyrazinamide, ethambutol and streptomycin) (38.7\%), fluoroquinolones (29\%), macrolides (16.1\%), cephalosporins (9.7\%), sulphonamides (3.2\%) and anti-fungal agents (3.2\%).

In the group of patients who experienced AEs, 29\% had previously experienced adverse reactions to other drugs. In 23 patients $(74.2 \%)$ the incriminated drug was discontinued, while in 8 patients (25.8\%), drug administration was continued because any newly apparent adverse reactions were mild, short-lasting or did not affect patient's health seriously, and it was considered safe to continue with drug administration.

Thirteen cases of anti-infective induced AEs (41.9\%) lasted for more than 5 days, while all others lasted fewerless than 5 days ( 3 to 5 days in 5 cases (16.1\%), 2 days in 6 cases (19.3\%), 1 day in 3 cases (9.7\%) and a few hours in 4 cases (12.9\%)).

The outcomes of the AEs were complete resolution of signs and symptoms in 20 cases (64.5\%), incomplete resolution of signs and symptoms in 10 cases (32.3\%), consisting mostly of elevated blood transaminase levels at the time of hospital discharge, and permanent damage in only one case (3.2\%), which had an audiometrically confirmed lesion of the acoustic nerve caused by anti-tuberculosis agents (most likely streptomycin).

The results of the Chi-squared analysis showed that there was no difference in duration of AEs between male and female patients. No statistically relevant difference in outcome of AEs or in previous experience of adverse reaction to drugs between male and female patients was found ( $\mathrm{p}>0.05$ ). On the other hand, the Chi-squared test analysis revealed that AEs described as diarrhoea and hypersensitivity reaction appeared more frequently in males than in females (test value-14.582, $\mathrm{p}=0.042$ ). Although there was no statistically relevant correlation between duration of AEs and patients' sex, a trend was found that AEs in females last longer than in males.

Finally, the results of our analyses indicate that males are at greater risk of experiencing adverse reactions to fluoroquinolones (ciprofloxacin) than females. Female patients are, on the other hand, at greater risk of experi- encing adverse reactions to anti-tuberculosis agents than male patients.

\section{DISCUSSION}

Many studies have been dedicated to investigation and analysis of AEs, focusing on various aspects such as causality, costs, consequences, hospitalisation, prolonging hospital stay and many others. It is easily noticed that there are great differences between the rates of adverse reactions to drugs reported from these studies. These differences may depend on the definitions used for AE and ADR, the study population, medications used for treatment, the method used for $\mathrm{AE} / \mathrm{ADR}$ assessment, the vigourintensity with which AEs were sought and the number of drugs administered simultaneously leading to drug interactions ${ }^{[5]}$.

Assessing AEs in inpatients is much easier and much more accurate than in outpatientsbecause because any potential adverse drug reaction is more easily perceived and monitored during hospital stay than in an outpatient setting. However, the probability that many AEs, even in inpatients, happen without being recorded is significant. Some of the effects of ADRs are often attributed to an underlying illness, previous medical history or other causes.

Anti-infectives appear to be first on the list of drugs causing ADRs. ${ }^{[5]}$ This is why we decided to conduct our study in the Center for Pulmonary Diseases, where antiinfectives are frequently used for various previously mentioned indications.

The incidence of AEs in inpatients receiving anti-infectives in our study (7.36\%) is within the range reported from other studies. ${ }^{[4,5,12,13]}$ Patients receiving therapy with anti-tuberculosis agents are at the greatest risk of experiencing ADRs. These agents are commonly used in combinations of 4 or 5 drugs (isoniazid, rifampicin, pyrazinamide, ethambutol and streptomycin), and although some adverse reactions are more likely to be attributed to one of them or some of them, they were jointly classified as antituberculosis agents because it is very difficult to be precise in selecting one of these drugs to incriminate for a specific adverse reaction. Nevertheless, these statistics imply the need to administer these drugs carefully and to monitor patients under therapy regularly to record any AEs promptly and to respond adequately. The second most frequent drug related to AEs in our study was ciprofloxacin, the most frequently prescribed antibiotic in the department.

Adverse events related to drugs in most cases led to prolonged hospital stay $(20.13 \pm 11.53$ days in patients with AEs, $18.16 \pm 14.36$ in patients total), which significantly increased the cost of hospital treatment.

It should be noted that none of the recorded adverse reactions to specific anti-infectives were unexpected. This raises a dilemma of whether a great portion of these ADRs were preventable or at least predictable. ${ }^{[14]}$

Another interesting issue that comes across in this study is the causality assessment. The fact that there were great differences in the rating/scoring of AEs recorded in this study shows that the abovementioned scales/sys- 
tems for causality assessment are not compatible or even comparable. The Naranjo probability scale is a tool used to determine the likelihood that an AE was caused by the implicated medication. Ten questions are answered and assigned a score of +2 to -2 . Where there is insufficient data available, that particular question receives a 0 . Based on the Naranjo criteria, each case is scored $(<1$ to $>9)$ and assigned a likelihood of causing an AE (doubtful, possible, probable, highly probable $)^{[9]}$.

Question No.7 assesses whether the drug was detected in the blood at toxic levels, which is not a routine or easily applicable procedure. Question No.4 ('Did the ADR appear with re-challenge?") is also problematic because it refers to re-administration of an incriminated drug to the patient, which few physicians are willing to allow. The same problem applies to question No.8 ("Was the reaction more severe when the dose was increased or less severe when the dose was decreased?"). In our survey, these questions were answered "No" in all cases. This explains why there were no AEs in our study classified as highly probable with score of 9 and more. The Naranjo scale is, therefore, applicable primarily to clinical trials and controlled conditions.

The WHO Causality Categories and European Causality Categories (ABO system) are similar, but the WHO Causality Categories are more detailed and therefore more precise (6 levels of adverse event rating) compared to the ABO system (only 3 levels of rating). The French Imputation System seems to be the most detailed and most precise. It has some of the faults already mentioned with the Naranjo Scoring System (drug re-challenging), but its greatest fault is that it is complicated and time-consuming. A rating system based on the French Imputation System consists of 3 phases: chronology (the time relationship between drug administration and the appearance of AE), semiology (the probability that the incriminated drug led to $\mathrm{AE}$ and/or other non-drug explanations) and literature grading (data from the literature where similar reactions to the incriminated drug were mentioned).

All of this implies that there is a great need for the development of new causality assessment scales with better sensitivity and specificity. These causality assessment scales (proposed and presently used) can reduce disagreement between assessors, classify relationship likelihood, help in marking individual case reports and be very useful in education and improvement of scientific assessment. On the other hand, it is not possible to expect to reach an accurate quantitative measurement of relationship likelihood, distinguish clearly valid from invalid cases, prove the connection between drug and event or quantify precisely the contribution of a drug to the development of an adverse event, thus increasing causal certainty, using these scales.

The results of this study indicate that physicians or pharmacists interested in investigating AEs related to drugs need to be simultaneously aggressive and cautious at the same timewhen recording and rating/scoring AEs. It seems that choosing adequate anti-infective therapy that is individually adapted to every patient and balanced between safety, efficiency and rationality remains a great challenge for every physician and every pharmacist.

\section{REFERENCES}

1. Bordet R, Gautier S, Le Louet H, Dupuis B, Caron J. Analysis of the direct cost of adverse drug reactions in hospitalized patients. Eur J Clin Pharmacol, 2001 Mar; 56 (12): 935-41

2. Pirmohamed M, James S, Meakin S, Green C, Scott AK, Walley $\mathrm{TJ}$ et al. Adverse drug reactions as cause of admission to hospital: prospective analysis of 18820 patients. BMJ, 2004;329:15-19 (3 July), doi:10.1136/ bmj.329.7456.15

3. Dormann H, Neubert A, Criegee-Rieck M, Egger T, Radespiel-Troger M, Azaz-Livshits T et al. Readmissions and adverse drug reactions in internal medicine: the economic impact. J Intern Med. 2004 Jun; 255 (6): 653-63.

4. Gholami K, Parsa S, Shalviri G, Sharifzadeh M, Assasi N. Anti-infectives-induced adverse drug reactions in hospitalized patients. Pharmacoepidemiology and Drug Safety, 2005 Apr; 14: 501-506

5. Weiss J, Krebs S, Hoffmann C, Werner U, Neubert A, Brune $\mathrm{K}$ et al. Survey of adverse drug reactions on a pediatric ward: A strategy for early and detailed detection. Pediatrics, Vol.110 No.2 August 2002: 254-257

6. Smith C. Adverse effects of antibiotics. US Pharmacist 1999; 24: 46-60

7. WHO Causality Categories. Drug Safety 1994; 10: 93-102

8. WHO collaborating center for international drug monitoring, the Uppsala Monitoring Centre. Adverse reaction Terminology, 1996.

9. Naranjo CA, Busto U, Sellers EM, Sandor P, Ruiz I, Roberst EA et al. A method for estimating the probability of adverse drug reactions. Clin Pharmacol Ther 1981;30: 239-45

10. RHB Meyboom and RJ Royer, Causality classification at pharmacovigilance centres in the European Community, Pharmacoepidemiol Drug Saf (1992) 1:87-97

11. Bégaud B, Evreux JC, Jouglard J, Lagier G. Unexpected or toxic drug reaction assessment (imputation). Actualization of the method used in France. Thérapie 1985; 40: 111-8

12. Lazarou J, Pomeranz BH, Corey PN. Incidence of adverse drug reactions in hospitalized patients: A metaanalysis of prospective studies. JAMA 1998 Apr 15; 279 (15): 1200-5

13. Van der Hooft CS, Sturkenboom MC, Van Grootheest K, Kingma HJ, Stricker BH. Adverse drug reaction-related hospitalisations: a nationwide study in The Netherlands. Drug Saf. 2006; 29 (2): 161-8

14. Gholami K, Shalviri G. Factors associated with preventability, predictability and severity of adverse drug reactions. Ann Pharmacother 1999; 33: 236-240 